for toddy. The stretch of arms in rowing demands no explanation, but it may be mentioned that the rowers were not engaged in rowing as they might be in England, but often continuously for long periods. Thus on first acquaintance they rowed (eighteen of them) forty-six miles to where I was, halted an hour or so to cook and eat a meal, and rowed back again the same distance, covering the ninety-two miles within twenty-four hours-not at all as a feat, but just in the ordinary way of work.

The climbing of the palms in this region needs some remarks, because whereas toddy-drawers are usually sustained by a strap round the back to ease the strain on the arms, in Malabar the whole weight of the body is borne by the arms alone, legs straight, feet held together by a grummet, the hands embracing the stem. Climbing in this manner is fatiguing, and when he has reached the top the climber works for about a quarter of an hour preparing the spathe, changing his pots, and so on, all the while upheld by the arms, which are thus on the stretch for a considerable portion of each day. It seemed, therefore, worth while to examine by careful measurements with instruments for anthropological work whether the continual straining of the arms during many generations affected the length of arms in relation to length of bodyheight. The result was that it did not. The arms of the hereditary rowers and of the hereditary climbers are no longer in proportion to height than of those engaged in occupations involving no strain of the arms. Writing far from home, I am unable to give you measures.

Algiers, January I2

\section{Popular Science Lectures on Natural History.}

THE lectures to juveniles at the Royal Institution by Prof. J. Arthur Thomson have been undoubtedly a great success, and I cannot help thinking that there are others, especially among our young men fresh from the universities, who could give lectures of this kind to popular audiences. If so, can they be discovered? They may be difficult to find, for success in this field requires a rare combination of gifts. It is absolutely necessary for such a lecturer to possess, besides knowledge and enthusiasm, a good voice and manner; his speech must be fairly loud, good, and clear, and his personality distinctly pleasing, or he will fail to win his audience. Unfortunately, few scientific men are good public speakers. It is also much to be regretted that many writers on biology and natural history adopt a style so learned and pedantic that both young and old are repelled.

Huxley, the younger Buckland, Gosse, and Hugh Miller are gone, and few follow in their steps. How sadly are the themes of beauty, mutual aid (so well treated by Kropotkin), and symbiosis neglected by modern writers! Those who do treat of these subjects seem to deal with them in a cold, dry way. The leading idea in Prof. Thomson's lectures is conquest by animals of the elements, and no other lecturer or writer has developed the subject as Prof. Thomson has done.

In conclusion, may I ask whether it would be possible to arrange courses of lectures on the same lines in different parts of London? It seems a pity that such lectures should be confined to the Royal Institution. Eager South London audiences can be found for Shakespeare's plavs, and I believe good lectures on natural history would also appeal to such audiences, especially if well illustrated and well delivered.

H. Neville Hutchinson.

Royal Societies' Club, January 10. No. 2674 , VOL. IO6]

\section{Angio-American University Library for Central Europe.}

In connection with the above library, we are endeavouring to supply the various university libraries on the Continent with the scientific journals they urgently need.

Among the periodicals for which we have received a pressing demand Nature is frequently mentioned, and I very much hope that you will be good enough to publish this letter in your columns so that any of your readers having copies of your journal from I9I4 onwards may hear of our appeal. Any numbers of the periodical which readers may feel they can dispense with will be gratefully welcomed.

The library is entirely non-political and non-sectarian, its sole object being to enable humanity at large to benefit in the future, as it has done in the past, from the research of European scholars. Such research has been brought almost to a standstill from the fact that European centres of learning have been cut off since I9I4, first of all by the blockade, and more recently by the exceedingly unfavourable position of the foreign exchanges, from English and American thought.

I fervently hope that some of your readers may be able to help in supplying the literary needs of Central Europe. A copy of the prospectus of the library will be gladly sent to anyone desiring a fuller account of its work and objects.

London School of Economics, Clare Market, Hon. Secretary. London, W.C.2, January $2 \mathrm{I}$.

\section{Greenland in Europe.}

Whatever lapse may be imputed to the London school-book of 1812 , noticed by Mr. MacRitchie in NATURE of January 13, p. 647 , it is not shared by the Rev. J. Goldsmith's "Geography, on a Popular Plan, Designed for the Use of Schools, and Young Persons," in its fifth edition at the earlier date of 1808 . For that author, in a very interesting account of Greenland, at p. 46 remarks that many so-called "ice islands" "are to be met with on the coasts of Spitzbergen, to the great danger of the shipping employed in the Greenland fisherv." He further instances the peril to which "Lord Mulgrave" was thus exposed in $I 77^{2}$, when by an opportune rising of the wind his ships, "after labouring against the resisting fields of ice, arrived at the west end of Spitzbergen." At this critical time, however, "Lord Mulgrave" was Capt. Phipps.

January 20.

T. R. R. S.

\section{Electric Light and Vegetation.}

Mr. PENDRED's interesting observations on the growth of vegetation beside the electric lights in the Cheddar caves (Narure, vol. cv., p. 709, August 5, I920) reminds me of some observations described by Mr. E. Cheel in the Australian Naturalist, vol. ii., 1912, p. I17. Of a number of plane-trees growing about Sydney railway station some were close to the large electric lights, and Mr. Cheel noticed that the branches nearest the lights retained their leaves from a month to a month and a half longer than the more distant branches of the same tree and than the trees distant from the lights. When the new leaves were opening in spring a similar period elapsed between the dates of opening of those near the lights and those distant therefrom, the branches subject to illumination being that much later in getting their leaves.

Sydney, New South Wales.
Thos. STEEL. 